\title{
CONGENITAL HEART DEFECTS FOLLOWING MATERNAL RUBELLA DURING PREGNANCY
}

\author{
BY \\ DOUGLAS STUCKEY \\ From the Royal Alexandra Hospital for Children, Sydney, Australia
}

Received October 14, 1955

The occurrence of various congenital anomalies, including heart defects, in children whose mothers had suffered from rubella during pregnancy was originally described by Gregg (1941) in Australia and these observations have been confirmed by many other workers. There is, however, surprisingly little detailed information available about the particular types of congenital heart defect that may occur. The matter is of considerable interest to cardiologists, for maternal rubella is one of the few known ætiological factors in congenital heart disease.

In Gregg's (1941) original report a patent ductus arteriosus was found at post-mortem examination in 3 infants. Swan et al. (1943) also found a patent ductus arteriosus at necropsy in 3 patients, and in one of these a small ventricular septal defect was present as well. Dogramaci and Green (1947) in a series of 434 cases of congenital heart disease found 5 patients whose mothers had suffered from rubella during pregnancy; patent ductus arteriosus occurred twice, Fallot's tetralogy once, and ventricular septal defect twice, one of these with pulmonary stenosis as an additional lesion. Jackson (1950) found seven children whose mothers had suffered from rubella during pregnancy among 343 cases of congenital heart disease proven at operation or at post-mortem examination: all seven had a patent ductus arteriosus and one of these had pulmonary stenosis and a small ventricular septal defect as well. Campbell (1949) among 243 cases found 4 following maternal rubella, all with Fallot's tetralogy and one with an atrial septal defect as well and two with cataract as well: two of these four followed rubella in 1940 during the same epidemic that was so severe in Australia. Gibson and Lewis (1952) reported 17 cases following maternal rubella, one each of atrial septal defect, ventricular septal defect, and Fallot's tetralogy, and in the remaining 14 a patent ductus arteriosus, combined with ventricular septal defect in two cases and with pulmonary stenosis and coarctation of the aorta in one each.

\section{MATERIAL}

This report is based on experience at the Royal Alexandra Hospital for Children over the five years up to December, 1953. A total of 426 patients suffering from congenital heart disease was examined during this period, and there were 44 who presented with a history of maternal rubella during pregnancy. Twenty-one of these were referred to the Congenital Heart Disease Clinic as part of a special survey of the rubella problem; the remainder were referred for opinion by other physicians. The ages of these patients ranged from 3 months to 12 years. A full blood count, a standard 12-lead electrocardiogram, and radiological examination were carried out in all cases. Of the 27 patients considered to have an actual cardiac defect, the diagnosis was confirmed in 7 at operation, in 6 by angiocardiography or cardiac catheterization, and in 7 at post-mortem examination.

RESULTS

Some details of the 44 patients are presented in Table I. Seventeen of them were considered 519 
Congenital Heart Disease following Maternal Rubella

\begin{tabular}{|c|c|c|c|c|c|c|c|c|c|c|c|c|}
\hline \multirow{2}{*}{ Diagnosis } & \multirow{2}{*}{$\begin{array}{l}\text { No. } \\
\text { of } \\
\text { cases }\end{array}$} & \multirow{2}{*}{$\begin{array}{c}\text { Associated } \\
\text { cardiac defects }\end{array}$} & \multirow{2}{*}{$\begin{array}{c}\text { Opera- } \\
\text { tion }\end{array}$} & \multirow{2}{*}{$\begin{array}{c}\text { Post- } \\
\text { mortem }\end{array}$} & \multirow{2}{*}{$\begin{array}{l}\text { Angio. } \\
\text { or } \\
\text { cathe- } \\
\text { ter }\end{array}$} & \multicolumn{3}{|c|}{ Other anomalies } & \multicolumn{4}{|c|}{$\begin{array}{l}\text { Rubella dur- } \\
\text { ing pregnacy } \\
\text { (months) }\end{array}$} \\
\hline & & & & & & Deaf & $\begin{array}{l}\text { Cata- } \\
\text { ract }\end{array}$ & Both & 1 & 2 & $\begin{array}{lll}3 & 4\end{array}$ & 57 \\
\hline $\begin{array}{l}\text { Innocent systolic } \text { mur- } \\
\text { mur } . . \\
\text { Patent ductus arteriosus }\end{array}$ & $\begin{array}{l}17 \\
13\end{array}$ & Small VSD-2 & $\overline{6}$ & $\overline{6}$ & $\begin{array}{l}1 \\
1\end{array}$ & $\begin{array}{c}12 \\
4\end{array}$ & $\overline{5}$ & 5 & 1 & 4 & $\begin{array}{l}7 \\
1\end{array}$ & 1 \\
\hline 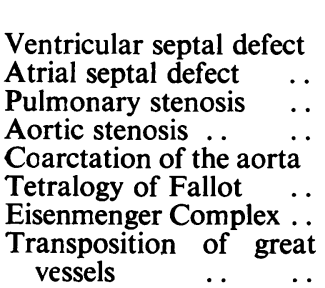 & $\begin{array}{l}4 \\
3 \\
1 \\
1 \\
1 \\
2 \\
1 \\
1\end{array}$ & $\begin{array}{l}\text { Mild PVS-2 } \\
\text { - } \\
\text { - } \\
\text { Aortic stenosis } \\
\text { - } \\
-\end{array}$ & $\begin{array}{l}\overline{-} \\
= \\
= \\
= \\
1\end{array}$ & $\begin{array}{l}E \\
= \\
= \\
= \\
1\end{array}$ & $\begin{array}{l}\frac{\overline{2}}{-} \\
\overline{2} \\
1 \\
-\end{array}$ & $\begin{array}{l}1 \\
1 \\
\frac{1}{-} \\
- \\
-\end{array}$ & $\begin{array}{l}- \\
- \\
-\end{array}$ & - & 1 & 1 & 1 & \\
\hline
\end{tabular}

to have a normal heart with an innocent systolic murmur. The criteria adopted in making this diagnosis have been discussed elsewhere (Stuckey, 1955), and may be stated briefly as a mid-systolic murmur of slight or moderate intensity, of short duration occupying no more than half of systole, usually loudest in the left parasternal line, and with no other abnormality to be found on clinical, radiological, or electrocardiographic examination.

In the 27 patients considered to have a congenital cardiac defect a wide variety of lesions was found. Thirteen had a patent ductus arteriosus, 4 a ventricular septal defect, 3 an atrial septal defect, 2 the tetralogy of Fallot, and one each suffered from aortic stenosis, pulmonary stenosis, coarctation of the aorta, the Eisenmenger complex, and transposition of the great vessels. Apart from patent ductus arteriosus, the relative incidence of the various lesions agreed closely with that found in the general population (Stuckey, 1954). Female preponderance (11:2) was found in those with a patent ductus arteriosus, and male preponderance $(12: 5)$ in those with an innocent systolic murmur, agreeing with the sex tendencies usually found in these conditions (Shapiro, 1939; Brown, 1950; and Stuckey, 1955, $a$ and $b$ ).

\section{Incidence of Congenital Heart Lesions following Maternal Rubella}

An attempt has been made to estimate the incidence of congenital heart defects following maternal rubella in the year 1940, at the height of the rubella epidemic in Australia. Various figures have been given for the proportion of live births showing any type of congenital anomaly following maternal rubella during pregnancy. Some Australian figures are 90 per cent (Swan et al., 1943), 30 per cent (Patrick, 1948), 75 per cent (Dods, 1951), and 70-80 per cent (Collins, 1953). Figures from America based on prospective studies are much lower (Ober et al., 1947; Ingalls and Purshottam, 1953). After discussion with others who saw the 1940 epidemic here, 50 per cent has been taken as a reasonably conservative figure for that particular time and place. It might be expected that, like any other virus, the virulence of rubella for the host tissues, fœtal or otherwise, would vary from time to time and from place to place.

The number of live births with congenital defects of any type following maternal rubella in New South Wales in the year 1940 was 178 (Gregg et al., 1945) and if we assume a 50 per cent incidence of congenital anomalies, then the total number of live births following maternal rubella in that year would have been about 356 .

Of our 27 patients with congenital heart defects following maternal rubella, 10 with patent ductus arteriosus and 6 with other congenital heart defects were born in 1940. The incidence therefore was 28 per thousand for patent ductus arteriosus, and 17 per thousand for other 
congenital heart lesions. For comparison, the normal incidence of congenital heart disease in the general population aged 3 months to 15 years has been given as 1.8 per thousand (Macmahon et al., 1953), and patent ductus arteriosus constitutes 18 per cent of these (Macmahon et al., 1953; Stuckey, 1954). The normal incidence of patent ductus arteriosus may thus be given as 0.3 per thousand, and that of the other congenital heart defects as 1.5 per thousand.

On these figures the incidence of patent ductus arteriosus in children born of mothers who had suffered from rubella during pregnancy in New South Wales in 1940 was about 88 times the normal, and the incidence of other congenital heart lesions about 11 times the normal.

\section{Multiple Cardiac Defects following Maternal Rubella}

In our own series the combination of a patent ductus arteriosus with another congenital heart lesion was found at post-mortem examination in 4 patients, a small ventricular septal defect in 2 cases, and pulmonary valve stenosis in 2 cases. Our patient with caorctation of the aorta was considered to have aortic stenosis as well on clinical grounds. Other observers have reported the association of patent ductus arteriosus with ventricular septal defect (Swan et al., 1943; Jackson, 1950; Gibson and Lewis, 1952), with pulmonary valve stenosis (Jackson, 1950; Gibson and Lewis, 1952), with coarctation of the aorta (Gibson and Lewis, 1952), and with aortic valve lesions (BonhamCarter et al., 1955). On the published figures, an additional cardiac lesion is likely to be present in about one-quarter to one-third of these patients with a patent ductus arteriosus.

\section{Cardiac Defects and Other Anomalies probably Due to Maternal Rubella}

In this series the association of a cardiac defect with deafness or cataract or both occurred in 9 of 13 patients with a patent ductus arteriosus, in 3 of 4 with a ventricular septal defect, in 3 with an atrial septal defect and in one each with pulmonary stenosis and aortic stenosis. Other observers (Dogramaci and Green, 1947) have reported the association of Fallot's tetralogy and cataracts in one patient.

\section{DisCUSSION}

It has been generally accepted that maternal rubella during pregnancy is causally related to a patent ductus arteriosus in the child, and the present report supports this view. In regard to the other congenital heart lesions, we must consider the increased incidence, the association with patent ductus arteriosus in the case of ventricular septal defect, pulmonary stenosis, aortic valve lesions and coarctation of the aorta, and the association with other specific evidence of fotal damage (deafness, cataracts). All these things suggest that maternal rubella may produce a wide variety of congenital heart defects in the child.

It has been shown that patent ductus arteriosus occurred about eight times more frequently than the other congenital heart lesions, compared with the normal relative incidence in the general population. A possible explanation can be offered for this interesting finding. The cardiac septa, the main vessels, and their valves are only susceptible to damage by environmental factors for a short period of some 4 or 5 weeks of fœtal life while they are being actively formed, the socalled "critical period" for these structures (Dods, 1951). The ductus arteriosus, on the other hand, is present for many months of fœtal life and for a short time after birth, and whatever the mechanism of final closure it is conceivable that it could be damaged at any stage. The greater incidence of patent ductus arteriosus in these children may thus merely reflect the longer time that this structure is at risk. If this explanation is accepted, the fact that patent ductus arteriosus does not predominate unduly over other congenital cardiac defects in the general population may suggest that genetic rather than environmental factors are responsible for the great bulk of cases of congenital heart disease.

Another point of interest is that whatever is responsible for the strong female preponderance in patent ductus arteriosus still operates in the post-rubella cases. Eleven of our 13 patients with a patent ductus arteriosus were girls. 
Most of our post-rubella cases resulted from the rubella epidemic of 1940 and succeeding years, but they continue to account for about 2 per cent of all congenital heart defects seen at this hospital. Since the present series closed we have observed four additional cases, one of aortic stenosis and three of patent ductus arteriosus, one of these with pulmonary stenosis as an additional lesion. The incidence in any community will obviously depend on the incidence and virulence of rubella affecting women during pregnancy.

Close inquiry amongst patients attending the Congenital Heart Disease Clinic over the last seven years regarding other illnesses complicating pregnancy has failed to incriminate any other infectious fever as a cause of congenital heart disease. In only three instances was such an illness reported, mumps twice and varicella once, and this small incidence may well have been due to chance. This does not deny the possibility that other infectious diseases in the mother may damage the developing fotus, and may only reflect the peculiar epidemiological characteristics of rubella and the greater susceptibility of adults, including pregnant women, to this disease.

\section{SUMmARY}

A wide variety of congenital heart defects in the child may follow maternal rubella during pregnancy. Twenty-seven such patients are reported, of whom 13 had a patent ductus arteriosus, 4 a ventricular septal defect, 3 an atrial septal defect, 2 the tetralogy of Fallot and one each aortic stenosis, pulmonary stenosis, coarctation of the aorta, the Eisenmenger complex and transposition of the great vessels.

Patent ductus arteriosus occurred about eight times more frequently than other forms of congenital heart disease compared with the normal relative incidence in the general population. A possible reason for this is suggested.

Thanks are due to Professor Lorimer Dods, of the Institute of Child Health, for his interest and encouragement.

\section{REFERENCES}

Bonham-Carter, R. E., Walker, C. H. M., Daley, R., Mathews, M. B., and Medd, W. E. (1955). Brit. Heart J., 17, 255.

Brown, J. W. (1950). Congenital Heart Disease. 2nd ed. Staples, London.

Campbell, M. (1949). Quart. J. Med., 18, 379.

Collins, I. S. (1953). Med. J. Aust., 2, 456.

Dods, L. (1951). Modern Trends in Padiatrics. Butterworth \& Co., London.

Dogramaci, I., and Green, H. (1947). J. Pediatrics, 30, 295.

Gibson, S., and Lewis, K. C. (1952). Amer. J. Dis. Child., 83, 317.

Gregg, N. McA. (1941). Trans. Ophth. Soc. Aust., 3, 35.

, Beavis, R., Heseltine, M., Machin, A. E., Vickery, D., and Meyers, E. (1945). Med. J. Aust., 2, 122.

Ingalls, T. H., and Purshottam, N. (1953). New Engl. J. Med., 249, 454.

Jackson, A. V. (1950). Studies in Pathology; Presented to Peter MacCallum. Melbourne University Press.

Macmahon, B., McKeown, T., and Record, R. G. (1953). Brit. Heart J., 15, 121.

Ober, R. E., Horten, R. J. M., and Feemster, R. F. (1947). Amer. J. Publ. Hlth., 37, 1328.

Patrick, P. R. (1948). Med. J. Aust., 1, 421.

Shapiro, M. J. (1939). Amer. Heart J., 17, 416.

Stuckey, D. (1954). Med. J. Aust., 2, 433.

- $(1955$, a). Med. J. Aust., $1,749$.

- $(1955$, b). Med. J. Aust., $2,841$.

Swan, C., Tostevin, A. L., Moore, B., Mayo, H., and Black, G. H. B. (1943). Med. J. Aust., 2, 201. 